\title{
A COMIC SCENE WITH A STOIC MESSAGE: TERENCE'S EUNUCHUS IN PERSIUS SATIRE 5.161-175
}

\author{
JC Zietsman (University of Stellenbosch)
}

\section{Introduction}

The Greek paraclausithyron is the song sung by the lover at his mistress's door as a part of the revel or komos which followed a symposium and after he had been refused admission to her house. It is usually a song of disappointment and sorrow, based on a more or less stereotyped incident: the lover's passage through the streets on his way to the girl's house after the symposium, her refusal to admit him into the house, and his lament in which he may combine a plea that the girl will relent, a warning of the lonely days to come when she will be too old for love, and a picture of his own sufferings. In the end he may hang his garland on the door or scribble some scraps of verse on the door. Then he lies down in the doorway to remain there until morning. ${ }^{1}$

The paraclausithyron caught the imagination of the Romans as it had never caught that of the Greeks (Copley 1956:28). It was Plautus who (in his Curculio, the earliest extant Roman paraclausithyron) gave the regular plea for admission as well as the exclusus amator motif a distinctively Roman colour: his most obvious innovation is the personification of the door, which is treated as if it were a living being. This leads to the further innovation that the lover's plea for admission is addressed not to the beloved (as in the extant Greek examples), but to the door itself (Copley 1956:36). As a result the Roman paraclausithyron receives an entirely new orientation: the door, rather than the girl, becomes the centre of interest, the key words used being fores, ianua and limen.

Although not all Roman paraclausithyra after Plautus are addressed to the door, the door does continue to play a prominent and distinctive part. Strangely enough, however, when Terence refers to the theme in the Eunuchus he shows no sign of independent additions or of any other native changes or developments but, if anything, a regression from the type established by Plautus to the earlier Hellenistic pattern (Copley 1956:43).

Apart from his other references to the conventional literary paraclausithyron (for example Epod. 11, Satires 1.4, Carm. 3.26) Horace's discourse on human follies (Satire 2.3) follows the passage in Terence closely, although his version is much shorter. However, unlike his model, Horace refers directly to the Plautine paraclausithyron: he makes a clear reference to the shut-out lover (amator / exclusus, lines 259-260) and features the door prominently (haeret / invisis foribus, lines 261262).

The scene also appears in Persius Satire 5 which is basically a poem about the nature of true freedom and how to obtain it. In lines 73-131 the arguments put forward by the poet and an imaginary interlocutor take the form of a diatribe on moral

1 See Copley 1956:1-6 for the general characteristics of the paraclausithyron. 
domination and enslavement - true freedom is not external, legal freedom, but the freedom obtained from spiritual knowledge (ratio, that is, philosophy): the only way to true freedom instead of moral slavery is through Stoicism. Persius illustrates this thesis that only the wise man is free in the final section of the poem (lines 132-191) by discussing examples of the mental passions that keep the non-Stoic enslaved: avaritia, luxuria, servitium amoris, ambitio and superstitio.

The exhortations and conflicting demands of the personified Avaritia (lines 132-140) and Luxuria (lines 141-160) both endeavour to enslave the man who heeds them (Zietsman 1995:113-118). Though Avaritia makes her case forcefully, Luxuria sees some of the snags and warns that even if the interlocutor does not follow her advice, he will not free himself from the demands of Avaritia either:
157 nec tu, cum obstiteris semel instantique negaris
158 parere imperio, "rupi iam vincula" dicas;
159 nam et luctata canis nodum abripit, et tamen illi,
160 cum fugit, a collo trahitur pars longa catenae. ${ }^{2}$

Even if you once succeed in making a stand and defying / their incessant orders, you can't say 'I've broken my bonds!' / For a dog may snap its fastening after a struggle, but still / as it runs away a length of chain trails from its neck. ${ }^{3}$

It is in this context that Persius includes the scene from Terence: the debate between Avaritia and Luxuria develops into a moral paradigm based on Terence's Eunuchus (Act 1, Scene 1), which is presumably an adaptation of the prologue of Menander's lost Eunuchus (Kissel 1990:723). In lines 161-175 the satirist depicts the indecisive condition of Chaerestratus who is torn between his passion for Chrysis and his perfect awareness of her faithlessness. ${ }^{4}$ Terence's characters are named Parmeno, Phaedria and Thais but these names are replaced in Persius by Davus (a common name for a slave in comedy), Chaerestratus and Chrysis. ${ }^{5}$ According to the scholiast Persius may be harking back to Menander for these names (Bo 1969:116; Harvey 1981:171).

That Persius would refer to Menander is not surprising: at the end of Satire 1 Persius describes the sort of reader he wants - one who has studied Cratinus, Eupolis, and Aristophanes (lines 123-124). So, not all Greek poetry was corrupt. New Comedy was also acceptable, and Menander, who was close to life in style and subject could also be admired as a critic of human follies (Rudd 1986:181) by a poet like Persius whose intention is to write his own, unique, truly Roman poetry, that is, satire with an ethical purpose: pallentis radere mores / doctus et ingenuo culpam defigere ludo ("you're adept at scraping unhealthy habits and nailing vice with a stroke of wit"; Sat. 5.15-16).

2 I have used Clausen's edition (1959) for quotations from Persius.

3 Translations of the passages quoted in this paper are based on Rudd 1979 and 1986.

4 It was a stock theme amongst Stoics to use love as an example of bondage, in contrast to true freedom (see Cic. Parad. 5.36).

5 The characters in Horace's version are anonymous. 
The purpose of this paper is to indicate that Persius has, however, also adapted other elements from his various predecessors' handling of the paraclausithyron to suit his own need, which is a philosophical interpretation of a well-known comic theme. He is not primarily concerned with using the exclusus amator theme in extenso, neither is his reference a mere obiter dictum: his concern is the nature of true freedom.

\section{Discussion of lines 161-175: Sexual passion as an example of moral slavery}

Persius illustrates the argument of lines 157-160 (quoted above): one person who cannot escape moral enslavement for very long is the lover who is dominated by his mistress. The young lover has decided to give up his pursuit of the girl (161-166); ironically, his adviser (167-168a) and source of wisdom is his slave, Davus. But then he thinks: "Suppose she asks me to come back? Should I go?" (168b). Davus' reply amounts to "all or nothing": "if you left her completely and left no part of you behind, not even now (that is, when she invites you) should you go" (169-174a). Emphasis is on completeness, and Persius draws the conclusion (174b-175): "here is the free man we are looking for, not in the meaningless ceremony of giving a slave his freedom" (Morford 1984:62).

161 'Dave, cito, hoc credas iubeo, finire dolores

162 praeteritos meditor' (crudum Chaerestratus unguem

163 adrodens ait haec). 'an siccis dedecus obstem

164 cognatis? an rem patriam rumore sinistro

165 limen ad obscenum frangam, dum Chrysidis udas

166 ebrius ante fores extincta cum face canto?'

167 'euge, puer, sapias, dis depellentibus agnam

168 a percute.'

168b 'sed censen plorabit, Dave, relicta?'

169 'nugaris. solea, puer, obiurgabere rubra,

170 ne trepidare velis atque artos rodere casses.

171 nunc ferus et violens; at, si vocet, haut mora dicas

172 "quidnam igitur faciam? nec nunc, cum arcessat et ultro

173a supplicet, accedam?"

$173 \mathrm{~b}$ si totus et integer illinc

174a exieras, nec nunc.'

174b hic hic quod quaerimus, hic est,

175 non in festuca, lictor quam iactat ineptus.

"Davus, look - I really mean it - I intend to put a stop

to the agony I've been through," Chaerestratus proclaims as he gnaws

his nails to the quick. "Why should I bring disgrace to my decent relatives, earning a bad name, squandering the family fortune outside a house of ill repute, singing drunkenly outside Goldie's dripping door when my torch has gone out?" "Splendid my boy! Now take my advice and slaughter a lamb 
for the gods who shield us from mischief."

"But Davus, do you think she'll cry when I leave her?"

"Nonsense, my boy! She'll give you a whack with her red slipper,

- that'll teach you to struggle and gnaw at the tight net!

Now you're wild and fierce, but if she called, at once you'd say:

'What'll I do? Not go near her, not even now

when she invites me - begs me?'

and genuine break."

Not even now, if you've made a clean

There, I tell you, is the freedom we're after, not in the piece of stick waved by a silly official.

This scene in Persius differs from the opening scene in both Terence's Eunuchus and in Horace Sat. 2.3.258-271. The latter is a free citation of the opening scene of Terence's Eunuchus. Horace makes a clear reference to the shut-out lover, mentions the door prominently, and refers to the lover's vigil before the closed door (Copley 1956:55): amator / exclusus qui distat, agit ubi secum, eat an non, / quo rediturus erat non arcessitus, et haeret / invisis foribus ("In the same way the lover, recently shut out, debates whether or not to call at the address he had meant to revisit until he was asked. He dithers at the hated door"; Hor. Sat. 2.3.259-262).

Although Horace's version of the scene condenses Terence's material, it is much closer to Terence than that of Persius: Horace treats love as a form of insania (Rudd 1986:211) and the lover's state of mind is seen as ridiculous; the childish behaviour described in lines 247-249 is typical of the childish conduct of the offended lover (lines 258-275). Both Terence and Horace also show the indecisiveness of the lover who is at a loss what to do: amator / exclusus qui distat, agit ubi secum, eat an non (Hor. Sat. 2.3.259-260).

Persius' imitation of the comedy is however sufficiently free to adjust the apparently traditional sequence of the opening scene of the Eunuchus. This adaptation enables him to accommodate the theme of temporary freedom (Bo 1969:116) although the practical implication of his argument will only be revealed in the final lines of this passage. Lines 161-163a immediately introduce a speech in which Chaerestratus declares his determination to sever all links with his mistress and to pull himself together. Unlike his Terentian or Horatian counterpart, Chaerestratus has already formed his intention when he appears (Rudd 1986:212-213).

Kissel (1990:724-726) argues that just as Persius probably named his characters after their counterparts in Menander's play, this difference in the opening scene could also have been based on Menander. The lovers in Terence and Horace never come to a decision; Chaerestratus' initial determination to leave his mistress, followed by his sudden change of heart in line 168, could well be what Kissel calls another "Handlungsmoment" from Menander. This affords Persius with the opportunity for another adaptation: Davus plays a much stronger and more decisive role in advising the young Chaerestratus than is the case in Terence and Horace.

However, that Chaerestratus' decision is not an easy one, is graphically portrayed: cito (line 161) abruptly introduces Chaerestratus' tension after he has been 
contemplating his decision on his own for a long time and now wishes to inform Davus of this decision (Kissel 1990:726). But he has also been biting his nails during his long private deliberation: crudum ... unguem / adrodens, (lines 162-163a). The biting of nails indicates an unusually heightened emotional state; crudum means "raw" or "bleeding" (T.L.L., iv. $1236.16 \mathrm{ff}$.). It is probably predicative, like vivos in Horace Sat. 1.10.71 (vivos et roderet unguis), although it could be attributive: Chaerestratus has been biting his nails "so hard and frequently that he now bites already bleeding nails" (Harvey 1981:171; Kissel 1990:727). ${ }^{6}$ The tension in these lines is also noticeably conveyed by the choice of words. In the first sentence consisting of nine words (lines 161-162a) there are five verbs or forms of verbs (credas, iubeo, finire, praeteritos, meditor) of which the short and nearly abrupt phrases are symptomatic of Chaerestratus' tension and nervousness.

Chaerestratus' reasons for his intention are also a new adaptation: he acknowledges that his affair with Chrysis has involved social disgrace, expense and personal degradation (163b-166). In line 163b siccis means "sober", abstemius, non vinosus (Bo 1969:116) and is contrasted with ebrius (line 166). Bo (1969:116) explains dedecus as turpissime vivens, and obstem as obsistam, officiam, incommodus sim.

The phrase limen ad obscenum reminds the reader that Chrysis is a meretrix: in this typical iunctura acris the limen is obscenum because the meretrix lives in a house of bad repute, a brothel, and therefore obscenum (Kissel 1990:727). Bo (1969:117) interprets the meaning of the phrase as ad limen domus Chrysidis meretricis. Harvey (1981:172) adds that the adjective suggests sensual eroticism, which is surely to be expected in a scene dealing with slavery to sex. However, meretrices are not always bad in the New Comedy or in Roman Comedy: in this context limen ad obscenum rather refers to an undesirable relationship. Since Chrysis is a meretrix, the relationship between her and Chaerestratus is unacceptable, a disgrace to the family of a free-born Roman. The sense of the context is therefore "shall I, a disgrace to my family because of this affair, oppose or go against (obstem) their wishes when they want the affair ended?" This element of remorse does not appear in Terence or in Horace.

Commentators give numerous explanations for $u d a s / \ldots$ ante fores (lines 165 166). All of these explanations fit the traditional characteristics of the paraclausithyron (see Copley 1956:1-4) and are not mutually exclusive. It is variously explained as "wet with ointment" (scholiast and Lucr. 4.1179), "wet with wine" (Hor. Carm. 1.7.22), or "wet with tears" (Prop. 1.16.4). It might also mean "wet with rain" (Hor. Carm. 3.10.19) or that water has been thrown down onto the lover (see i.a. Némethy 1903:296; Raschke 1976:91-92; Harvey 1981:172). One more obvious explanation is probably that the adjective udas is transferred from the lover who is ebrius (line 166), "soaked with wine". To these explanations Kissel (1990:728-729) adds the possibility that the door could be udas as a result of the lover's kisses (Mart. 8.44.5, mane sudas urbis osculis udus).

Nailbiting as a sign of high emotional stress is also used by Persius in Sat. 1.106.

See also Lucil. 239 M.; Hor. Carm. 1.18.3 and Epist. 1.19.9. 
Horace's treatment of the lover's situation as ridiculous is also present in Persius: extincta cum face (line 166) is meant to heighten the absurdity of the lover's conduct. (Torches were carried by the lover and his friends on their way from the symposium to the house of the mistress.) The torch could be out because of the lover's long wait for admission as in Propertius 1.16.8, exclusi signa iacere faces (Harvey 1981:172; Kissel 1990:729). It could of course also have been extinguished by rain (Némethy 1903:296), by the lover's tears, or by wine, probably as a result of his drunken carelessness (Conington 1874:110) or of course by the water thrown out by the meretrix (Lee \& Barr 1987:153). Once again these explanations all fit the general characteristics of the paraclausithyron, and the adjectives udas and ebrius together with the phrase extincta ... face therefore all function as descriptive words in setting the drunken scene of revelry.

Chaerestratus' words in lines 163b-166 evoke the following remark from Davus, who represents the voice of reason: 'euge, puer, sapias, dis depellentibus agnam / percute' (167-168a). The interjection euge (often found in comedy) is here one of approval as Davus praises the decision of his master. With the colloquial sapias (167), which is also often found in comedy, the poet probably means si sapis as in Martial 4.54.3: si sapis, utaris totis, Colline, diebus. The form sapias (translated by Nisbet-Hubbard 1970:140 as "be sensible") is also used in Horace Carm. 1.11.6-7: sapias, vina liques, et spatio brevi / spem longam reseces. ${ }^{8}$ Davus instructs his master to kill (percute, line 168) a lamb (agnam, line 167) as a sacrifice to the dii depellentes. They were the gods who averted evil things ${ }^{10}$ and the sense of the expression is gratias age diis qui te salvum volunt (Bo 1969:117).

But Chaerestratus has not yet in actual fact broken away from his mistress: he has only been thinking about such a possibility (Kissel 1990:731). Chaerestratus' doubt is strikingly introduced by sed and his indecision is made more explicit by the fact that he formulates his doubt as a question in line $168 \mathrm{~b}$ : 'sed censen plorabit, Dave, relicta?' It is here that the temporary nature of his freedom is graphically illustrated: Chaerestratus is indeed nothing more than a moral slave - in this instance a slave to sexual passion: the prospect of his mistress' tears, implying the possibility that she might relent, immediately impedes his firm resolve (tears are also mentioned in Ter. Eun. 67-69; there is no crying in Horace).

It is important to note here that the lover comes "home" from a feast, drunk (ebrius, line 166), and finds himself excluded (ante fores, line 166). Greek paraclausithyra are distinctly divided into a dramatic and non-dramatic type. In the dramatic type (of which very few examples remain) the incident may end with the lover's rejection or his reception, depending on the requirements of the plot. In the non-dramatic type he is never admitted (Copley 1956:7, 17). In the Roman tradition the door always remains closed although Plautus' Curculio is atypical in that it has

See also Ovid Am. 1.4.29: quod tibi miscuerit, sapias, bibat ipse, iubeto.

This is a sacrificial term; cf. Ovid Fast. 1.347: percussi viscera tauri.

10 Apollo and the Dioscuri were among the deities universally recognised in this character. The more common word is averrunci (Varro L.L. 7.102). 
the "happy end" sometimes seen in the Greek dramatic tradition (Copley 1956:3334).

The motive for ending the love-affair is therefore revenge for being excluded, and does not come from the lover's heart. Chaerestratus is also angry - he does not really want to break free, but wants to revenge himself on his mistress: if she admits him again (cum arcessat et ultro / supplicet, lines 172-173) he would gladly go back. But then the dolores (line 161) will start all over again, so Davus issues a crisp warning to remind him of the humiliation he can expect at the hands of his mistress: 'nugaris. solea, puer, obiurgabere rubra' (line 169).

Kissel (1990:729-730) detects a fatherly affection in Davus' words to the young Chaerestratus. Apart from addressing him as puer for the first time in line 167 and praising his decision to end his affair with Chrysis, the warning that he will be beaten with a slipper is typical of the kind of threat used to discipline disobedient children. But when Chaerestratus is addressed as puer again in line 169, the whole context has changed: puer can also mean "slave" or "servant" (see also Pers. Sat. 5.126). The result is that Davus, a slave, represents moral freedom and ironically addresses his master, a legally free man, as puer, here referring to his moral enslavement to his mistress (Kissel 1990:730).

The reference in solea is to the tale of Hercules and Omphale, the Lydian queen (also alluded to in Ter. Eun. 1026-1028). Omphale is represented as having beaten Hercules with her sandal, when, in expiation of a murder, he became her slave (Lee \& Barr 1987:153). In later versions of the tale Hercules becomes the slave of Omphale out of love for her (Ovid A.A. 2.221; Prop. 3.11.17-20). Omphale's beating of Hercules with a slipper is a comic device (soleae were the usual footwear in Roman Comedy), perhaps also imitated from Menander (Kissel 1990:731). In Persius the sandal is called rubra probably to suggest a rich and demanding woman (Bo 1969:118; Harvey 1981:173). With reference to Horace Carm. 1.35.12 (purpurei... tyranni) Kissel (1990:732) points out that slippers were also often made of purple material and sees in rubra an allusion to the almost tyrannical power that Chrysis has over her lover.

In continuation of the image in lines $157-160$ of the dog trailing a chain from its neck, Chaerestratus is represented as an animal caught in a snare, trying to escape (line 170). The verb obiurgabere (line 169), "chastise", is often used for correction compare i.a. Petronius 34.2 , colaphis ... obiurgari puerum ... iussit. ${ }^{11}$ The meaning of trepidare (line 170) of beasts who will not submit to the yoke is neatly illustrated by Propertius 2.4.5-6, sic primo iuvenes trepidant in amore feroces, / dehinc domiti post haec aequa et iniqua ferunt (Némethy 1903:298; Harvey 1981:173). An animal trapped in the net tries to get out by gnawing through the meshes: artos rodere casses (line 170). Conington (1874:111) detects a reference to the Aesopean fable of the lion and the mouse, in which case Persius has given the role of the mouse to the ensnared animal. The line must be read in close connection with what follows in lines 171-173: Davus censures his master's lack of consistency (169-174a); he therefore does not tell

11 The original meaning of obiurgo was that of verbal abuse, extended in post-Augustan usage to blows: $O L D$ s.v., 2. 
his master not to struggle, but not to struggle at one time and give way at another (see also Kissel 1990:732-734).

The temporary nature of the lover's freedom in contrast to the moral freedom of the slave is clearly illustrated: nunc ferus et violens (171) refers to the lover's decision (161-163a) to leave his mistress - for the moment he is angry and indignant but will eventually cool off and reconsider. So, Davus scornfully anticipates the lover's traditional vacillation, mocking his indecision: at si vocet, haut mora dicas, / quidnam igitur faciam? nec nunc, cum arcessat et ultro / supplicet, accedam? (171173). The lines are a conflation of Terence Eun. 46-47, quid igitur faciam? non eam ne nunc quidem / quom accersor ultro? and Horace Sat. 2.3.262-263, nec nunc, cum me vocet ultro, / accedam? (Harvey 1981:174).

The phrase nec nunc (172), which stands for ne nunc quidem, is strongly accentuated by nec nunc in line 174a. This repetition is intensified by the repetition of hic which appears three times in line 174b: hic hic quod quaerimus, hic est, / non in festuca, lictor quam iactat ineptus. (Persius recalls his references to the manumission ceremony which he mentioned in his discussion on the difference between civil and moral freedom in lines 73-131. The lictor is called ineptus because he is engaged in a meaningless ceremony that does not convey real freedom.)

The effect is that Davus' reaction is accentuated; it is in these lines that the actual meaning of lines 161-175 lies hidden. Persius is not primarily describing the lover's inability to break free from his mistress as one of the examples of moral slavery. This traditional interpretation of lines $161-175$ originated from the view that ille / in venerem putris (57-58), which refers to the lecher as one of the examples of futile human pursuits, foreshadows lines 161-175. However, Persius is rather illustrating how the moral slave can break free from sexual enslavement or any other kind of moral enslavement, namely by breaking totally: totus et integer illinc / exieras (173-174). If the lover has freed himself totus et integer from domination by his mistress he should not even return when he is asked and begged to do so. The adjectives totus and integer have the same sense, namely that of "without leaving any part of you behind" (Conington 1874:111).

Persius is sterner and more decisive than his predecessors. Terence and Horace both allow their slaves to indulge in some aimiable, roundabout, reflections on the psychology of love. Davus, however, showing independence of mind, sticks to his text, which is true, Stoic, freedom as distinct from the formal emancipation conferred by the praetor (Rudd 1986:213). The slave's attitude therefore represents true moral freedom in the Stoic sense in contrast to the moral servitude of his master, Chaerestratus. Not only is this scene a lively example of servitium amoris, but it also illustrates graphically that just as legal freedom does not guarantee moral freedom, the legal position of a slave does not necessarily constitute a slavish mentality (Kissel 1990:736).

Lines $174 \mathrm{~b}-175$ contain the poet's concluding remarks on the whole scene between Chaerestratus and Davus: "This is the kind of freedom we are looking for: a complete change of heart." Freedom is not something that can be gained through legal freedom (festuca) which is worthless (ineptus), but it lies in the ability to turn away 
from moral enslavement: Chaerestratus, a legally free man, was freed from his enslavement to sexual passion as a result of the advice of his slave, a sapiens, and therefore a morally free man.

To conclude: Persius' description of the scene between Chaerestratus (the typical slave to passion) and Davus (representing the voice of reason) serves as a literary, specifically picturesque exemplum in his discussion of freedom. In true Stoic fashion he treats love as an example of bondage, an enslaving passion (Lee \& Barr 1987:152-153; Witke 1970:106; see also Morford 1984:62). His originality lies in his individual handling of the paraclausithyron, using this traditional comic theme to demonstrate that real freedom includes the ability to escape the servitium amoris.

\section{BIBLIOGRAPHY}

Bo, D 1969. A Persi Flacci Saturarum liber. Torino: Paravia.

Clausen, W V 1959. A. Persi Flacci et D. Iuni Iuvenalis Saturae. (repr. 1968) Oxford: Clarendon Press.

Copley, F O 1956. Exclusus amator: A study in Latin love poetry. Oxford: Blackwell.

Conington, J \& Nettleship, H 1874. The Satires of A. Persius Flaccus. (2nd ed.) Oxford: Clarendon Press.

Harvey, R A 1981. A commentary on Persius. Leiden: Brill.

Kissel, W 1990. Aules Persius Flaccus Satiren. Heidelberg: Carl Winter.

Lee, G \& Barr, W 1987. The Satires of Persius. Liverpool: Cairns.

Morford, M 1984. Persius. Boston: Twayne.

Némethy, G 1903. A Persii Flacci Satirae. Budapest: Hungarian Academy.

Nisbet, R G M \& Hubbard, M 1970. A commentary on Horace: Odes Book 1. Oxford: Clarendon.

Raschke, W J 1976. Literary and historical studies in the satires of Lucilius and Persius. Diss. State University of New York.

Rudd, N 1979. Horace: Satires and Epistles; Persius: Satires. Harmondsworth: Penguin Books.

Rudd, N 1986. Themes in Roman satire. Norman: University of Oklahoma Press.

Witke, C 1970. Latin satire: The structure of persuasion. Leiden: Brill.

Zietsman, J C 1995. The rhetoric of a Stoic poet (Persius Satire 5). Akroterion 40(34):106-119. 